\title{
Train Station Performance Evaluation Based On Minimum Service Standard (Case Study: Cikarang Station, West Java)
}

\author{
Budi Dermawan Widodo ${ }^{\mathrm{a}^{*}}$, Fibriyanto Nurul ${ }^{\mathrm{b}}$ \\ ${ }^{a}$ Faculty of Engineering, University Mercu Buana Jakarta, Indonesia, wbdermawan@ gmail.com \\ ${ }^{b}$ Faculty of Engineering, University Mercu Buana Jakarta, Indonesia, nurulumb2015@ gmail.com
}

\begin{abstract}
As the population grows and the economic level in the Cikarang area increases the movement of the people. Provision of mass transportation or transportation using the train is very necessary to anticipate the congestion that will occur by providing this train station can be an alternative. Therefore, it is necessary to conduct research to assess the performance and quality of service to to find out how much the level of passenger satisfaction with the service performance of the cikarang station. The method used is the Importance Performance Analysis (IPA) and Chi Square Squares. This study uses 100 respondents for each method. Station performance that does not meet Minimum Service Standards such as waiting rooms, boarding rooms and passenger service facilities. From the analysis obtained the average value of the level of passenger satisfaction with the services and facilities of the Cikarang Station, namely the value of the level of performance with an average weight of 3.17 and the value of satisfaction with an average weight of 3.17, from the highest score of 5 and the lowest score 1. Chi Square Test on the Station Cikarang shows that service factors that significantly influence passenger satisfaction are cleanliness and comfort of the toilet.
\end{abstract}

Keywords: SPM, Impotance Performance Analysis (IPA), Chi Square.

\section{Introduction}

The station is where the train departs and stops to serve the ups and downs of passengers and/ or loading and/ or for the purposes of train operations, So we need facilities that can support the needs of these users. This user's needs are also contained in the Minister of Transportation Regulation No. 48 of 2015 concerning Minimum Service Standard for Transportation of People by Train at the Station.

The application of minimum service standard at Cikarang Stations based on Minister of Transportation Regulation No 48of 2015 is expected recommendations for better station performance service. Good service, starting from booking tickets until the departure of important reduirements for customers. There fore it is deemed necessary to conduct a study of the level of service and facilities at the suitability of service to the Minimum Service Standard No.48 of 2015.

The objectives of this study include :

1. Get an average number of passengers during peak hours

2. Knowing the suitability level of the building area and dimensions of the Cikarang Station platform based on Minister Regulation No.29 of 2011

3. Knowing the performance and service facilities of Cikarang Station based on Minister Regulation No. PM 48 of 2015

4. Knowing the level of passenger Station services and facilities.

\footnotetext{
* Corresponding author.

E-mail address: wbdermawan@gmail.com (Budi Dermawan Widodo)
} 


\section{Methodology}

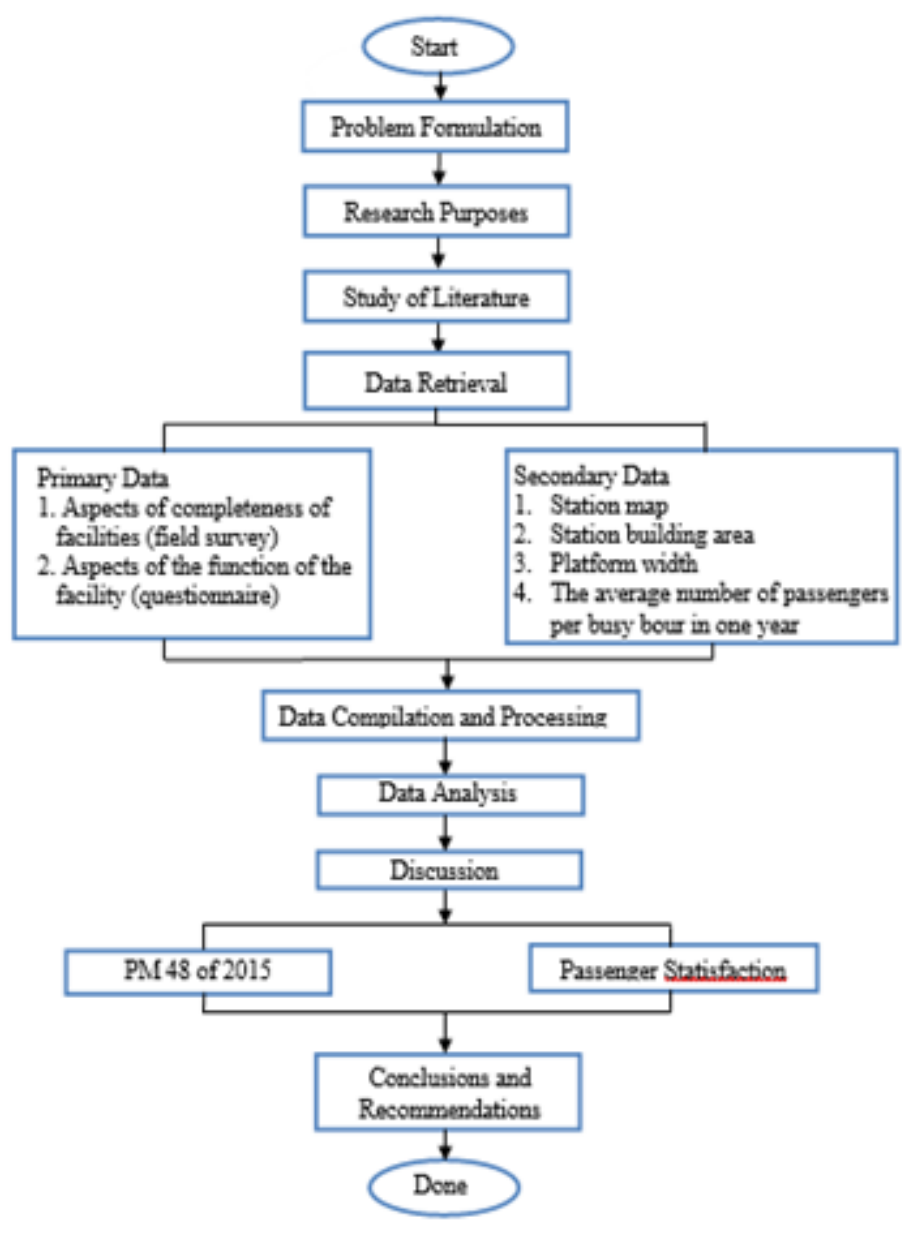

Figure 1 Flow Diagram

Source : Research Data

\subsection{Average Number of Passengers}

Based on data obtained from the Indonesia Commuter train, PT ia as follows :

Table 1. Average Number of Passengers in Cikarang Station

\begin{tabular}{cccc}
\hline Year & Per Year & Weekday & Weekend \\
\hline 2019 & 5.688 .712 & 16.132 & 18.157 \\
\hline \multicolumn{2}{l}{ Source $:$ Research Data }
\end{tabular}




\subsection{The Building Area of Cikarang Station}

Based on the regulation of the Minister of Transportation No. 29 of 2011 concerning the technical requirements of the train station building, the main activity building at the station can be calculated by formula :

$$
L=0.64 \mathrm{~m}^{2} / \text { person } \times V \times L F
$$

It is know that the number of train passenger movements at Cikarang Station in 2019 was 5.688 .712 people/year. The busiest house at the station are $07.00-10.00$ and $15.00-20.00$, then the area of the Cikarang Station building can be calculated as follows :

$$
\begin{aligned}
L \quad & =\left(0.64 \mathrm{~m}^{2} / \text { person }\right) \times(5.688 .712 / 365 / 8) \times 0.8 \\
& =997,47 \mathrm{~m}^{2}
\end{aligned}
$$

The area of the main building is based on the total daily passengers during rush hour on work days.

$$
\begin{aligned}
L \quad & =\left(0.64 \mathrm{~m}^{2} / \text { person }\right) \times(16.132 / 8) \times 0.8 \\
& =1032,45 \mathrm{~m}^{2}
\end{aligned}
$$

The area of the main building is based on the total daily passengers during peak hours on holidays.

$$
\begin{aligned}
L \quad & =\left(0.64 \mathrm{~m}^{2} / \text { person }\right) \times(18.157 / 8) \times 0.8 \\
& =1162,05 \mathrm{~m}^{2}
\end{aligned}
$$

Based on data from the operating area 1 Jakarta in the form of the floor plan Cikarang station, the area of main activities in the station can be seen in the following table:

Table 2. Building Area main activities

\begin{tabular}{clc}
\hline No & Room type & Room size $\left(\mathrm{m}^{2}\right)$ \\
\hline 1 & Hall & 846,40 \\
2 & R. Tickets & 52,20 \\
3 & R. Poskes & 17,33 \\
4 & R. Mushola & 77,76 \\
5 & R. Toilet & 72,25 \\
\hline & Total & 1065,94 \\
\hline
\end{tabular}

Source : Research Data

Based on the table above, there is a wide area of main activities in Cikarang station of $1065.94 \mathrm{~m} 2$, while the area of the main activity of the count is calculated in the Ministerial regulation No 29 year 2011 namely $997.47 \mathrm{~m} 2$, on weekdays (weekday) $1032.45 \mathrm{~m} 2$ and Holiday (weekend) $1162.05 \mathrm{~m} 2$. It can be concluded that the building area needed for the main activities of Cikarang station is currently sufficient for the area of the building.

\subsection{Construction platform at Cikarang station}

The high-level platform designed at Cikarang station for placement, quantity and width are as follows :

1. Number of platform lines at Cikarang station

North Side There are 4 special active lines of non-KRL trains (lines 6 and 7: straight gauge).

On the south side there are 4 special lines KRL (line 2 and 3: Spur straight). At the edge of the platform given the secure boundary line between $40-60 \mathrm{~cm}$, this safe boundary is a yellow line with the surface arising. 
2. Number of platforms

The North Side is 4 ( 1 of the high-stair side platforms and 3 rather low-level island platforms). On the south Side 2 island platforms are equally high.

3. Platform width

The station platform width can be calculated using the formula:

$$
B=\left(\left(0,64 \mathrm{~m}^{2} / \text { person }\right) \times V \times L F\right) / l
$$

Where (V) is the number of passengers per rush hour in one year (person). Then the platform Length (l) is adjusted to the longest circuit of the passenger trains operating. The busiest hour at the station is at $07.00-10.00$ and at $15.00-$ 20.00 , while the maximum length of the train series that can operate is 12 cars with the length of each carriage is 20 meters. It is known that the number of passenger transfers at Cikarang station in 2019 is 5,688,712 people/year. The calculations are as follows:

$$
\begin{aligned}
b & =\left(0.64 \mathrm{~m}^{2} / \text { person } x(5.688 .712 / 365 / 8) \times 0.8\right) / 210 \\
& =4,75 \text { meter }
\end{aligned}
$$

From the calculations obtained the platform width of 4.75 meters while the width of the platform at the current Cikarang station $5 \mathrm{~m}$. Then it can be concluded that the width of the platform needed today is sufficient for the existing platform.

\section{Average Calculation Passenger Response Analysis}

The result of the above calculation and the average calculation result of the performance assessment and satisfaction

\begin{tabular}{|c|c|c|c|c|c|}
\hline & \multirow{2}{*}{$\begin{array}{l}\text { Elements - elements in the Minimum } \\
\text { service standard }\end{array}$} & \multicolumn{2}{|l|}{ Assessment } & \multirow{2}{*}{$\mathrm{X}$} & \multirow{2}{*}{$\mathrm{Y}$} \\
\hline & & Performance & Satisfaction & & \\
\hline & Safety & & & & \\
\hline 1 & Information and safety facilities & 340 & 318 & 3.40 & 3.18 \\
\hline 2 & $\begin{array}{l}\text { Health information and facilities } \\
\text { Security }\end{array}$ & 323 & 337 & 3.23 & 3.37 \\
\hline 3 & Security Faciltas & 351 & 365 & 3.51 & 3.65 \\
\hline 4 & $\begin{array}{l}\text { Security Interruption Information } \\
\text { Reliability/Regularity }\end{array}$ & 283 & 271 & 2.83 & 2.71 \\
\hline 5 & Certainty of getting tickets & 390 & 393 & 3.90 & 3.93 \\
\hline 6 & $\begin{array}{l}\text { Ease of getting tickets } \\
\text { Comfort }\end{array}$ & 388 & 389 & 3.88 & 3.89 \\
\hline 7 & Clean and comfortable room/waiting area & 321 & 348 & 3.21 & 3.48 \\
\hline 8 & $\begin{array}{l}\text { The atmosphere of the station } \\
\text { (crowded/Lenggang) }\end{array}$ & 314 & 307 & 3.14 & 3.07 \\
\hline 9 & Service officers were & 330 & 335 & 3.30 & 3.35 \\
\hline 10 & Cleanliness and comfort toilet & 351 & 294 & 3.51 & 2.94 \\
\hline 11 & $\begin{array}{l}\text { The cleanliness and comfort of the mosque } \\
\text { Ease }\end{array}$ & 359 & 376 & 3.59 & 3.76 \\
\hline 12 & $\begin{array}{l}\text { Facilities of boarding/dropping the train } \\
\text { (platform) }\end{array}$ & 272 & 291 & 2.72 & 2.91 \\
\hline 13 & $\begin{array}{l}\text { Advanced installation Information (map, } \\
\text { KRL route, etc) } \\
\text { Equality }\end{array}$ & 339 & 348 & 3.39 & 3.48 \\
\hline
\end{tabular}
of passengers can be seen in the table below:

Table 3. calculation of average passenger rating 


\begin{tabular}{lllclc}
\hline \multirow{2}{*}{$\begin{array}{l}\text { Elements }- \text { elements in the Minimum } \\
\text { service standard }\end{array}$} & \multicolumn{2}{l}{ Assessment } & \multirow{2}{*}{ X } & \multirow{2}{*}{ Y } \\
\cline { 2 - 4 } & Performance & Satisfaction & & \\
\hline 14 & Accessibility provided for disabled needs & 278 & 270 & 2.78 & 2.70 \\
15 & Special space for mothers and babies & 115 & 112 & 1.15 & 1.12 \\
\hline Average Total Service Quality (X,Y) & & & $\mathbf{3 . 1 7}$ & $\mathbf{3 . 1 7}$ \\
\hline
\end{tabular}

Source : Research Data

From the average calculation of each dimension of service as a whole, as follows:

1. Average of the quality of service dimensions for the performance of Cikarang station reached the value of 3.17 then on average, it can be said that the performance for the service of each dimension has reached the category good enough.

2. The average level of passenger satisfaction in each dimension reaches the value of 3.17 so on average, it can be said that the level of satisfaction of passengers for the service of each dimension has reached the category quite satisfied.

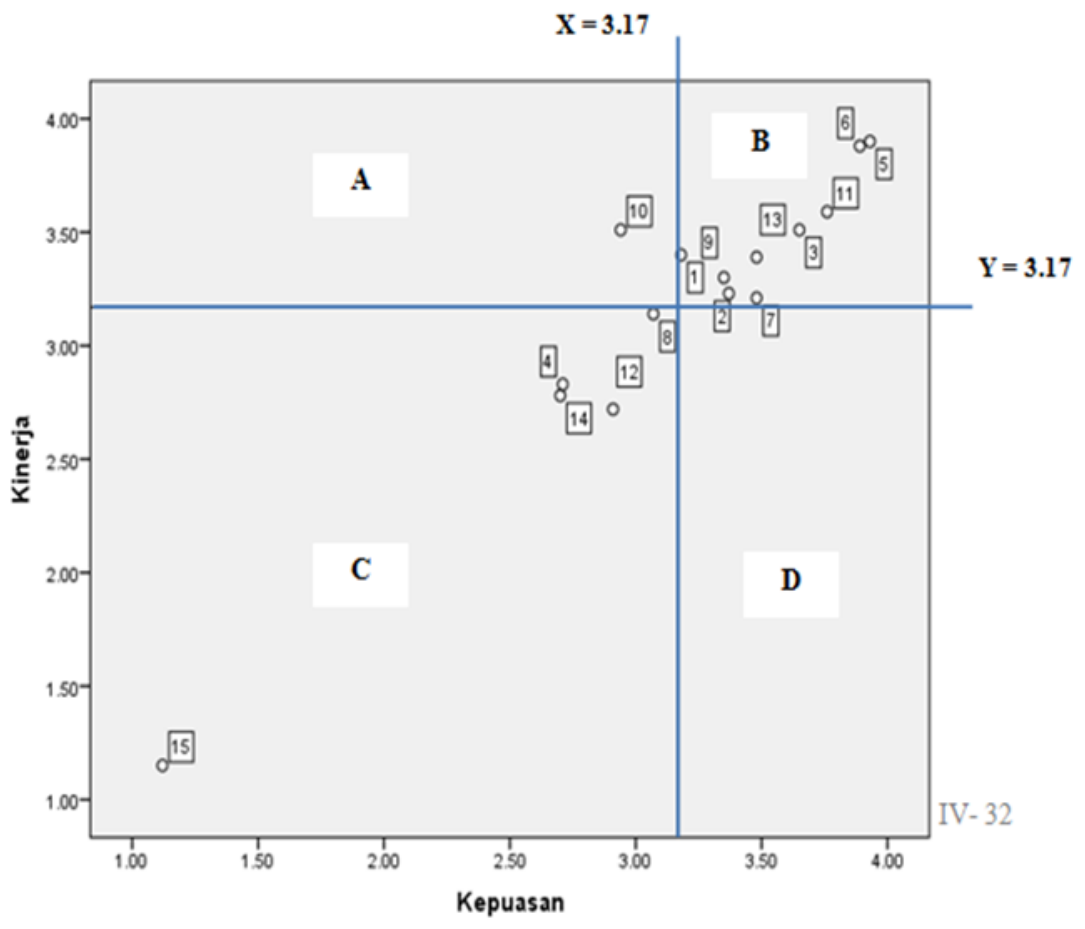

Figure 2 Cartesian Chart Graph

Source : Research Data

Result of processed questionnaire data described as Cartesuis diagram "Importance Performance analysis" above, we can describe the research result as follows:

1. Service factors that are a top priority in handling or

Factors that are considered to affect satisfaction, including the elements of service that are deemed very important by the customer to be in the quadrant A diagram of Cartesius "Importance Performance Analysis", where the average performance under the average total-average service factor and average-average satisfaction above the average total-service factor. In this study, only the "cleanliness and comfort of toilets" in the quadrant.

2. Service factors that should be maintained performance performance 
The service factor that should be maintained performance is a factor of service that resides on the B quadrant diagram of "Importance Performance Analysis" Cartesius, as follows:
a. Information and safety facilities
b. Health information and facilities
c. Security Personnel Services
d. Certainty of getting tickets
e. Ease of getting tickets
f. Clean and comfortable room/waiting area
g. Station Attendant Services
h. The cleanliness and comfort of the mosque
i. Advanced Transport Information

3. Low priority service factors in handling aktor

The low priority service factor is located in the $\mathrm{C}$ quadrants of Cartesius diagram "Importance Performance analysis", as follows:
a. Security Interruption Information
b. Atmosphere in the station (comfortable/crowded)
c. Facilities of boarding/dropping the train (platform)
d. Accessibility provided to disabled special needs
e. Special room/place for nursing mothers and infants

4. Factors of service with excessive performance

Excessive service factors are on the Quadrant D Cartesius diagram of the "Importance Performance Analysis", wherein the average performance above the average total of the service factor and the average-average satisfaction below the average total-service factor. In this study, there was no ministry factor in the D quadrant.

\section{Data Result Analysis}

1. From the calculations that refer to regulation of the Minister of Transportation No 29 year 2011, that the needs of the building area of the main activity of Cikarang station is $997.47 \mathrm{~m} 2$, on weekdays $1032.45 \mathrm{~m} 2$ and holidays $1162.05 \mathrm{~m} 2$. While the area of main activities in Cikarang station is $1065.94 \mathrm{~m} 2$. So the building does not need to expand.

2. Based on the results of the count referring to regulation of the Minister of Transportation No 29 year 2011, obtained the platform width of 4.75 meters while the width of the platform at Cikarang station is currently $5 \mathrm{~m}$. So there is no need to expand the platform.

3. Based on the observation data, the performance obtained by Cikarang station that has not fulfilled Minimum service standards (SPM), including:
a. Lounge
b. Boarding Room
c. Pasesenger service facilities

4. The service factor that does not affect the passenger satisfaction is significantly located in the $\mathrm{C}$ Quadrant, while the service factor affecting the passenger satisfaction is significantly on the quadrant A and B.

\section{Conclusion}

Based on the research and analysis done at Cikarang station, it can be concluded as follows:

1. The average number of passengers at Cikarang station during peak hours reaches 5,688,712 per year, on the average working day of the passenger reaches 16,132 and on the day of the average passenger reaches 18,157 people.

2. From the calculations that refer to regulation of the Minister of Transportation No 29 year 2011, that the needs of the building area of the main activity of Cikarang station is $997.47 \mathrm{~m} 2$, on weekdays $1032.45 \mathrm{~m} 2$ and holidays $1162.05 \mathrm{~m} 2$. While the area of main activities in Cikarang station is $1065.94 \mathrm{~m} 2$. So the building does not need to 
expand. Based on the results of the platforms are obtained a platform width of 4.75 meters while the width of the platform at Cikarang station is currently $5 \mathrm{~m}$. So there is no need to expand the platform.

3. Based on the observation data, the performance obtained by Cikarang station that has not fulfilled Minimum service standards (SPM), including: Ruang tunggu
a. Lounge
b. Boarding room
c. Passenger service facilities

4. The average level of passenger satisfaction to the service and facilities at Cikarang Station is satisfied with the average weight of 3.17 from the highest score of 5. While the average performance assessment of Cikarang station is good with an average weight 3.17 of the highest score.

\section{Recommendation}

From the results of the research and analysis of data, to improve the service to the passengers at the station Cikarang, it is recommended that the following:

1. To improve the quality of service, PT. KAI can upgrade some facilities at Cikarang station which are not yet compliant with Minimum service standards (SPM)

2. To improve the satisfaction of passengers at Cikarang station, it is necessary to repair several factors that are still under the expectation of passengers, by improving the following services:
a. Security Interruption Information
b. Atmosphere in the station (comfortable/crowded)
c. Facilities of boarding/dropping the train (platform)
d. Accessibility provided to disabled special needs
e. Special room/place for nursing mothers and infants

3. This research is done only at Cikarang station, for further research can be done at other stations that are deemed necessary to do research problems that exist.

\section{References}

Aji Laksono, Raden.,(2013), "Evaluation of train station performance based on Minimum service standards (case study station prused Cirebon, West Java)". University Atma Jaya Surabaya

Br Sembiring, Evaliata dan Eliaser Firnando Tarigan., (2014), "Application of computer applications in the Analysis of service quality, facilities and price to customer satisfaction (Case study: AC Economy train Yogyakarta) ", Journal of Accounting, economics and business management Vol. 2(2) (148-153. Batam: Politeknik Negeri Batam

Greetika et.al.,(2015), Jurney Towards World Class Stations : An Assessment of Platform Amenities at Allahabad Junction". National Institute of Technology

Intari, Dwi Esti. Irma Suryani., dan Iswati Septya., (2017), "Evaluation of the performance of Bogor railway station services in Bogor, West Java". University of Sultan Ageng Tirtayasa

Kirana, Rimas K. et.al,(2017)," Review of train station performance (case study of Kediri station and Mojokerto station)". University of Brawijaya

Mardhani, Mega Adventia.,(2016),“Comparison of maintenance management facilities and infrastructure of Tugu railway station with Purwokerto station",Yogyakarta: University of the Victoria

Nuryadi, Irvan dkk.,(2017), "Evaluation of passenger lounges performance (case study of Semarang Poncol station, Central Java)". University of Diponegoro

Oky Pranata, Alfian., (2017)," Measurement of customer satisfaction local train services cross Solo - Yogyakarta". Muhammadiyah University of Jakarta

Regulation of the Minister of Transportation Republic of Indonesia number PM 29 year 2011, "Technical Requirements building railway station", Indonesia 
Regulation of the Minister of Transportation of Republic of Indonesia number PM 48 year 2015, "minimum service standard by train people", Indonesia

Regulation of the Minister of Transportation Republic of Indonesia number PM 33 year 2011, "type, class and activity train station", Indonesia

Rismiana Sari, Risna., (2013)," Train station performance evaluation based on Minimum service standards ". State Polytechnic University of Bandung

Sulistiyani, Maulya W., (2017)," Performance evaluation of Surabaya Pasar Turi station. University of Technology Institute of Ten November (ITS)

Syahirul Alim, Ahmad. Achmad Wicaksono., dan Hendi Bowoputro.,(2014)," Performance evaluation of train station Malang Kota Baru based on SPM K. A and IPA". University of Brawijaya.Examples: APA Style and we suggestion to using Mendeley. 